\title{
Responding Human Needs in Iranian Traditional Houses in Psychological Approach (Case study: Haghighi House, Isfahan, Iran)
}

\author{
Reihaneh A. Sajad* and Samaneh A. Sajad \\ *Postgraduate Department, Daneshpajoohan Higher Education Institute, Isfahan, Iran. \\ Faculty of Architecture, Islamic Azad University of Esfahan (Khorasgan), Isfahan, Iran. \\ *sajad@daneshpajoohan.ac.ir
}

\begin{abstract}
Human being is an egocentric creation, which select and behave based on his/her ego's benefits. The most important motivation for human is satisfying the needs. Psychological Researches have shown that these needs are the same in all people. Houses as physical base of forming family, participate in satisfaction of needs in some aspects. Iranian traditional houses, have been preparing good quality of life for their residents in their life period, and therefore it seems that it is somehow because of facilitating the basis of need satisfaction. In this research, literature of human needs has been collected and categorized, and after that this needs has been surveyed in Haghighi house as a case study in descriptive and Logical analysis method. Haghighi house is a traditional house in Isfahan, Iran, from Qajar Period (early $19^{\text {th }}$ century). Although the examples are from this house, but it has been tried to identify some general aspects of Iranian traditional houses. At the end some strategies for designing contemporary houses toward more satisfaction of human needs has been derived.
\end{abstract}

Keywords: Human needs, Iranian traditional houses, Haghighi House, Isfahan, Iran.

\section{INTRODUCTION}

It seems that there is a strong connection between the pleasurable experience of fulfillment of needs and well-being (Korhonen, 2013). "The idea of common human needs provides a superior theoretical framework with which to conceive of human welfare, which overcomes each of the critiques leveled against preference satisfaction" (Gough, 2014). The most of works, behaviors, and reactions of human can be interpreted in term of "human needs" and his preferences. They are powerful sources of explanation of behavior and social interaction of human being (Coate \& Rasati, 1988). Needs are innate rather than learned (Deci \& Ryan, 2000), and therefore they are common between all people, and Satisfying needs is essential for healthy development and effective functioning (Deci \& Ryan, 2000). Also needs are the link between performance and demand of the social world (Deci \& Ryan, 2000), and therefore to have healthy individuals and society, needs satisfaction is essential. Many psychologists have researched about human motivations and need;

Maslow divides human needs to four types that must be satisfied before a person can act unselfishly. These needs are in a hierarchical order, and for upward climbs one set of needs should be satisfied at a time. These needs are physiological needs, need for safety, the desire for love, and the quest for esteem. Maslow name these needs as "deficiency needs" besides "being needs" or "selfactualization" (Griffin, Andrew, \& Glenn, 1991) (Thielke, et al., 2012).

He defined the need for self-actualization as "the desire to become more and more what one is, to become everything that one is capable of becoming". People gravitate to maximize their potential in a gentle but persistent way, only after satisfaction of their basic deficiency cravings (Maslow, 1943).

Max-Neef classifies the fundamental human needs as existential needs and axiological (value) needs.

$\begin{array}{llll}\text { - } & \text { subsistence } & - & \text { leisure } \\ \text { - } & \text { protection } & - & \text { creation } \\ \text { - } & \text { affection } & - & \text { identity } \\ \text { - } & \text { understanding } & - & \text { freedom } \\ \text { - } & \text { participation } & & \end{array}$


Each need occurs at four different levels of activity: Being, Having, Doing and Interacting (Table.1). These needs are the same everywhere, while the means of satisfying a need may be highly variable in terms of time, culture and environment (Max-neef M. A., 1991) (Max-neef, Elizalde, \& Hopenhayn, 1992).
In addition needs can be satisfied in different intensities and levels. For example needs are satisfied within three context:

- With regards to self (Eigenwelt)

- With regards to the social group (Mitwelt)

- With regards to the environment (Umwelt) (Max-neef M. A., 1991).

Table 1: The Matrix of human needs by Max-neef (Max-neef M. A., 1991)

\begin{tabular}{|c|c|c|c|c|}
\hline $\begin{array}{l}\text { Fundamental } \\
\text { Human Needs }\end{array}$ & $\begin{array}{c}\text { Being } \\
\text { (qualities) }\end{array}$ & $\begin{array}{c}\text { Having } \\
\text { (things) }\end{array}$ & $\begin{array}{c}\text { Doing } \\
\text { (actions) }\end{array}$ & $\begin{array}{c}\text { Interacting } \\
\text { (settings) }\end{array}$ \\
\hline subsistence & $\begin{array}{l}\text { physical and } \\
\text { mental health }\end{array}$ & $\begin{array}{l}\text { food, shelter } \\
\text { work }\end{array}$ & $\begin{array}{l}\text { feed, clothe, } \\
\text { rest, work }\end{array}$ & $\begin{array}{l}\text { living environment, } \\
\text { social setting }\end{array}$ \\
\hline protection & $\begin{array}{l}\text { care, adaptability } \\
\text { autonomy }\end{array}$ & $\begin{array}{l}\text { social security, health } \\
\text { systems, work }\end{array}$ & $\begin{array}{l}\text { co-operate, plan, } \\
\text { take care of, help }\end{array}$ & $\begin{array}{c}\text { social environment, } \\
\text { dwelling }\end{array}$ \\
\hline affection & $\begin{array}{l}\text { respect, sense of } \\
\text { humor, generosity, } \\
\text { sensuality }\end{array}$ & $\begin{array}{l}\text { friendships, family, } \\
\text { relationships with } \\
\text { nature }\end{array}$ & $\begin{array}{l}\text { share, take care of, } \\
\text { make love, express } \\
\text { emotions }\end{array}$ & $\begin{array}{c}\text { privacy, } \\
\text { intimate spaces } \\
\text { of togetherness }\end{array}$ \\
\hline understanding & $\begin{array}{c}\text { critical } \\
\text { capacity, } \\
\text { curiosity, intuition }\end{array}$ & $\begin{array}{c}\text { literature, } \\
\text { teachers, policies } \\
\text { educational }\end{array}$ & $\begin{array}{c}\text { analyses, study, } \\
\text { meditate, } \\
\text { investigate }\end{array}$ & $\begin{array}{l}\text { schools, families } \\
\text { universities, } \\
\text { communities, }\end{array}$ \\
\hline participation & $\begin{array}{l}\text { receptiveness, } \\
\text { dedication, } \\
\text { sense of humor }\end{array}$ & $\begin{array}{l}\text { responsibilities, } \\
\text { duties, work, } \\
\text { rights }\end{array}$ & $\begin{array}{c}\text { cooperate, } \\
\text { dissent, express } \\
\text { opinions }\end{array}$ & $\begin{array}{l}\text { associations, } \\
\text { parties, churches, } \\
\text { neighborhoods }\end{array}$ \\
\hline leisure & $\begin{array}{l}\text { imagination, } \\
\text { tranquility } \\
\text { spontaneity }\end{array}$ & $\begin{array}{l}\text { games, parties, } \\
\text { peace of mind }\end{array}$ & $\begin{array}{l}\text { day-dream, } \\
\text { remember, } \\
\text { relax, have fun }\end{array}$ & $\begin{array}{l}\text { landscapes, intimate } \\
\text { spaces, places to be } \\
\text { alone }\end{array}$ \\
\hline creation & $\begin{array}{l}\text { imagination, boldness, } \\
\text { inventiveness, } \\
\text { curiosity }\end{array}$ & $\begin{array}{l}\text { abilities, skills, } \\
\text { work, } \\
\text { techniques }\end{array}$ & $\begin{array}{l}\text { invent, build, } \\
\text { design, work, } \\
\text { compose, } \\
\text { interpret }\end{array}$ & $\begin{array}{c}\text { spaces for } \\
\text { expression, } \\
\text { workshops, } \\
\text { audiences }\end{array}$ \\
\hline identity & $\begin{array}{l}\text { sense of belonging, } \\
\text { self-esteem, } \\
\text { consistency }\end{array}$ & $\begin{array}{l}\text { language, religions, } \\
\text { work, customs, } \\
\text { values, norms }\end{array}$ & $\begin{array}{l}\text { get to know } \\
\text { oneself, grow, } \\
\text { commit oneself }\end{array}$ & $\begin{array}{c}\text { places one belongs } \\
\text { to, } \\
\text { everyday settings }\end{array}$ \\
\hline freedom & $\begin{array}{c}\text { autonomy, } \\
\text { passion, self-esteem, } \\
\text { open-mindedness }\end{array}$ & equal rights & $\begin{array}{l}\text { dissent, choose, } \\
\text { run risks, develop } \\
\text { awareness }\end{array}$ & anywhere \\
\hline
\end{tabular}

Alderfer (1969), Speaks about needs in term of needs for existence, relatedness, and growth instead of Maslow's theory (Alderfer, 1969).

Andersen and her colleagues (1997) Mention human needs/motivations as:

- return." They believe that this specially reflected as attachment. This need is profoundly influential and may even practically dwarf the others.

- $\quad$ Autonomy Needs; it is opposing need to connection, as detachment from others in the form of individual autonomy and
- Human connection; "the need to feel connected with other people, the longing to be close, and the desire to experience tenderness, caring, and warmth from others and to be able to provide it in personal freedom or the need for selfdetermination. The need to experience a locus that is distinguishable from an external locus, and also from internal loci that reflect the mere adaptation of external forces. 
- Mastery needs; in the word of sense of personal mastery, competence and control.

- Meaning needs; that reflects the motivation to comprehend life, to have a discernment on the basis of this understanding. Operating across culture, provides a framework for action and identity ${ }^{1}$.

- Security need; the need to feel safe and secure (Anderson, Inga , \& Serena, 1997) (Andersen, Chen, \& Carter, 2000)

1) This is to comprehend and make sense of their experience, specially, difficulties and tragedies of life (Andersen, Chen, \& Carter, 2000).

According to Glasser theory there are two basic human needs to be satisfied;

1) Physical needs are the needs to survive, to prepare food, shelter and safety.
2) Psychological needs are spoken in term of;

- Belonging: to be with people who know, care about, and to be accepted and appreciated.

- Gaining power: knowledge and skills and therefore self-esteem.

- Having fun.

- Being free: to rehabilitate self (Glasser, 1999).

Whether we are aware of it or not, we are all the time behaving to meet these needs (Glasser, 1999). Deci and Ryan speak about three innate of fundamental psychological needs; Competence, autonomy, and relatedness, which defeated satisfaction of them causes negative functional consequences for mental health and often sequels in persistence and performance (Deci \& Ryan, 2000). Frey and Wilhite categorize needs in five basic ones: The need for survival, belonging, power/self-worth, freedom and fun (Frey \& Wilhite, 2005).

Table 2: Human needs categorization

\begin{tabular}{|c|c|c|c|c|c|c|c|c|}
\hline \multicolumn{2}{|c|}{ Needs } & $\begin{array}{c}\text { Maslow } \\
1943\end{array}$ & $\begin{array}{c}\text { Max-neef } \\
1991- \\
1992\end{array}$ & $\begin{array}{c}\text { Alderfer } \\
1969\end{array}$ & $\begin{array}{c}\text { Anderson } \\
1997\end{array}$ & $\begin{array}{c}\text { Glasser } \\
1999\end{array}$ & $\begin{array}{c}\text { Deci \& } \\
\text { Ryan } \\
2000\end{array}$ & $\begin{array}{c}\text { Frey \& } \\
\text { Wilhite } \\
2005\end{array}$ \\
\hline \multirow{2}{*}{$\begin{array}{l}\text { Physiologi } \\
\text { cal }\end{array}$} & \multirow[t]{2}{*}{ Physiological } & Physiological & Subsistence & Existence & & Physical & & Survival \\
\hline & & \multirow[t]{2}{*}{ Safety } & \multirow{3}{*}{ Protection } & & \multirow[t]{2}{*}{ Security } & & & \\
\hline \multirow[t]{3}{*}{ Connection } & \multirow[t]{2}{*}{ Love } & & & & & & & \\
\hline & & Love & & Relatedness & \multirow[t]{2}{*}{ Connection } & Belonging & \multirow[t]{2}{*}{ o Relatedness } & Belonging \\
\hline & Participation & & $\begin{array}{l}\text { Participati } \\
\text { on }\end{array}$ & & & & & \\
\hline \multirow[t]{5}{*}{ Autonomy } & Understanding & \multirow[t]{4}{*}{ Esteem } & \multirow{3}{*}{$\begin{array}{l}\text { Understan } \\
\text { ding } \\
\text { Leisure }\end{array}$} & & & & \multirow[t]{5}{*}{ Autonomy } & \\
\hline & Fun & & & & & Fun & & Fun \\
\hline & Identity & & & Growth & Autonomy & & & \\
\hline & \multirow[t]{2}{*}{ Freedom } & & \multirow{3}{*}{$\begin{array}{l}\text { Identity } \\
\text { Freedom }\end{array}$} & & & & & \\
\hline & & \multirow[t]{3}{*}{$\begin{array}{l}\text { Self- } \\
\text { actualization }\end{array}$} & & & & Freedom & & Freedom \\
\hline Competence & Competence & & & & Mastery & $\begin{array}{l}\text { power } \\
\text { Gaining }\end{array}$ & Competence & $\begin{array}{l}\text { Power/sel } \\
\text { f-worth }\end{array}$ \\
\hline Meaning & Meaning & & & & Meaning & & & \\
\hline
\end{tabular}




\section{RESEARCH METHOD}

According to above mentioned categorization of needs, we can divide needs in two major categories named physiological (subsistence, physical, survival, existence) and psychological (axiological) needs. The psychological needs could be categorized to Connection, autonomy, competence and meaning need (Table 2). We can speak about connection in term of love (belonging, or protection/affection), and participation. The autonomy need include understanding, fun (leisure), identity, and freedom needs (Diagram 1).

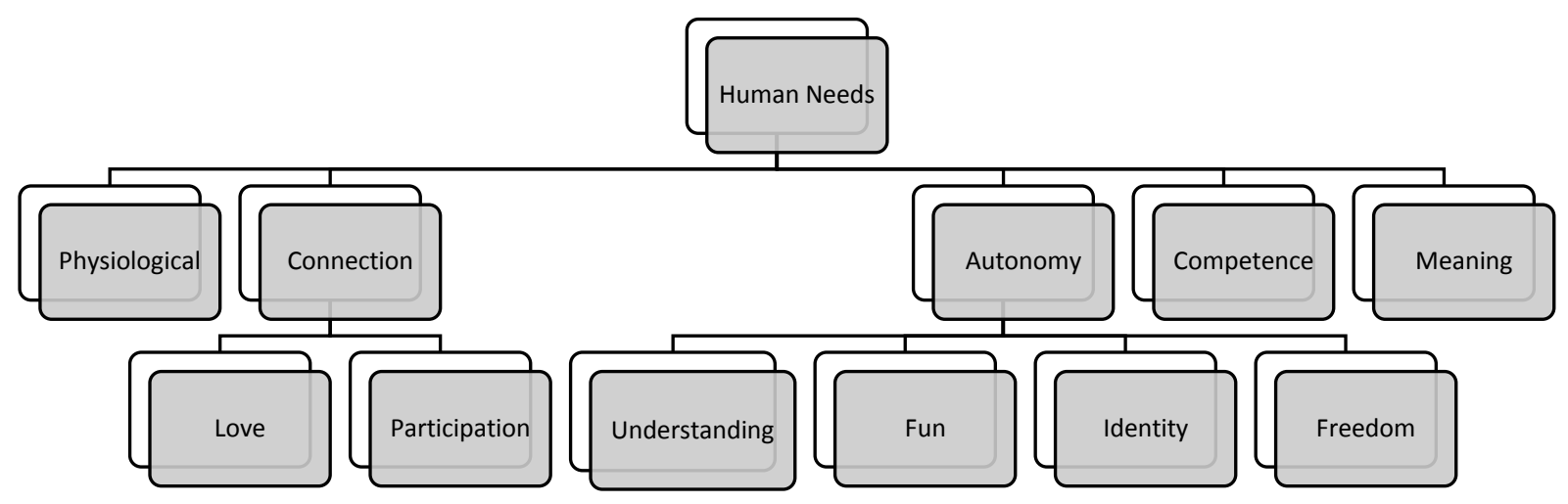

Diagram 1: Human needs

The traditional houses along history were more satisfying than today ones. In this survey, Haghighi house as a case study has been taken and the most common factor and elements - which are the same in most of traditional houses- in relation to needs satisfactions has been studied.
Haghighi house has built in early Qajar period in the $19^{\text {th }}$ century. The house is belonged to a private owner and in the early 1975 winter house was bought by Iran government, and transferred to Ministry of Art and Culture. From 1980 till now Art University of Isfahan is the owner of that (Abdul Rahim, 2013).

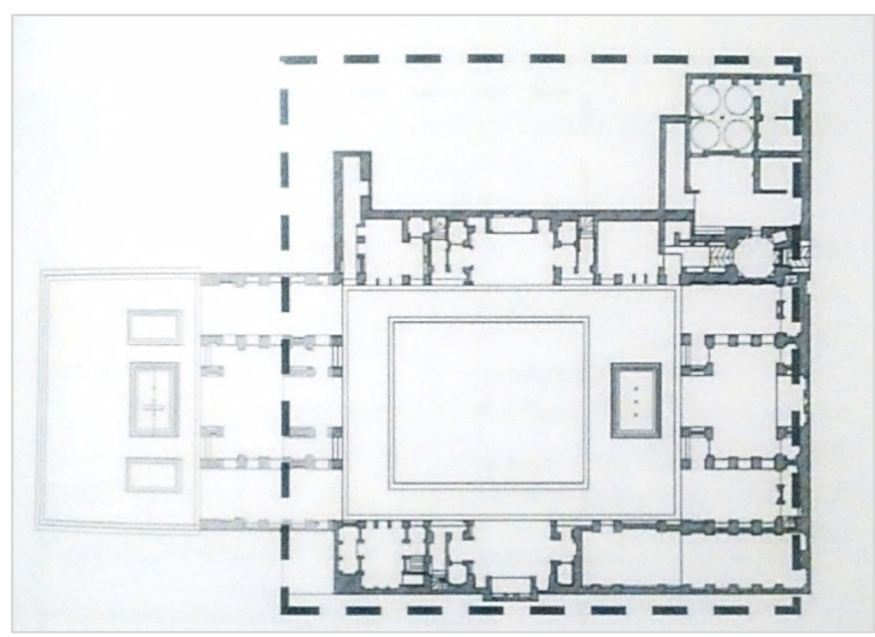

Figure 1: Plan of Haghighi House (Abdul Rahim, 2013) 


\section{DISCUSSIONS}

As before said, houses as a context of everyday life, participate in satisfaction of human needs;

The most important role of every house is to be a shelter, to response physical needs; to save people from danger, rain, sunlight, and also a place to make family, to become together, etc. (Figure 2). Also a base to develop protectiveness in relation to protection need. As Heidegger mentions; "Things of this sort are housings, though not necessarily dwelling-houses in the narrower sense" (Heidegger, 1971). Therefore all houses prepare a minimum of physiological needs, but they are different in psychological ones;

\section{- The need for Love}

Because of life style at traditional families in Iran, affection and belonging need is responded at traditional houses in a reasonable way; the hierarchy to reach the house, the arrangement of rooms around a yard like sitting around a table (Figure 3), the colorful places which increase sympathy (Figure 4). All of these items bring people together to live and act in a united group and it increases their belonging. Different places in houses with their own character facilitate forming memories and it is effective in shaping sense of attachment to place and other people.

\section{- The need for participation}

Living in a large home with a broad family increase human participation in each works. In other hand the main place for day life is central yard and many works are done in common. In traditional houses there are large rooms for family to come together and benefit each other presence (Figure 5).

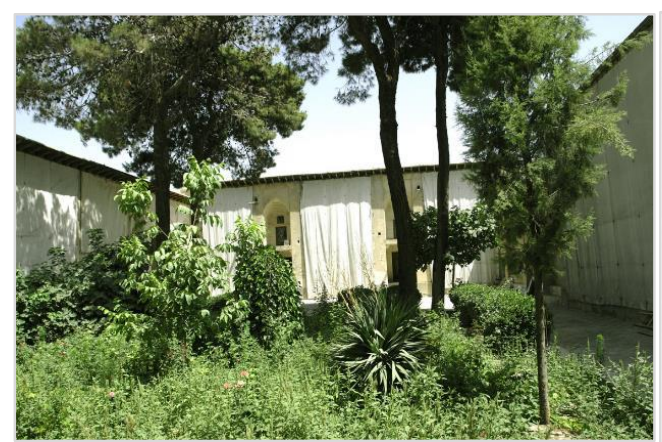

Figure 2: Haghighi house as a shelter

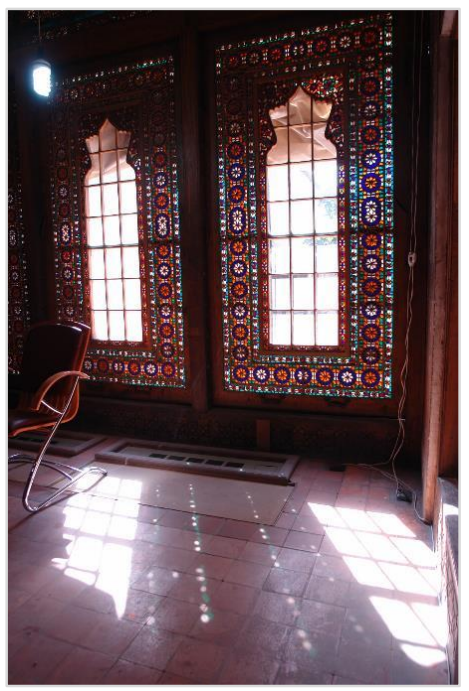

Figure 4: Colorful places of houses

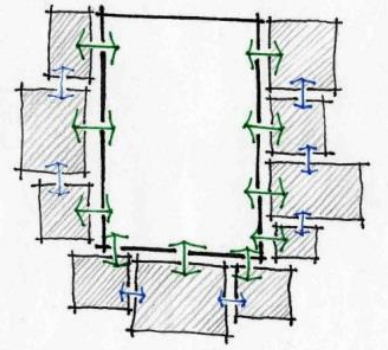

Figure 3: Arrangement of rooms around central yards

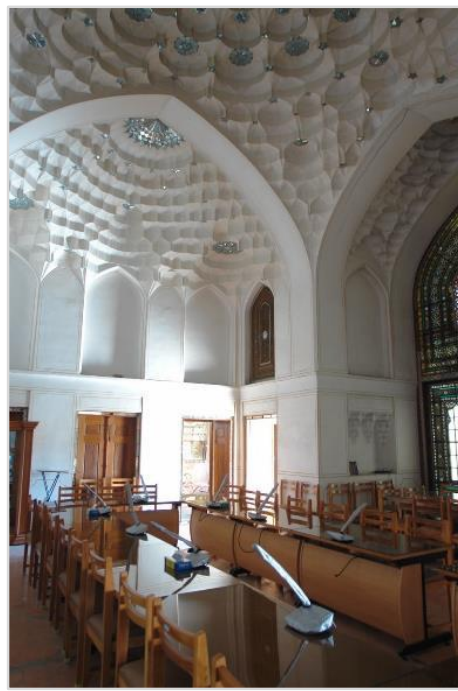

Figure 5: Large rooms to facilitate family participation

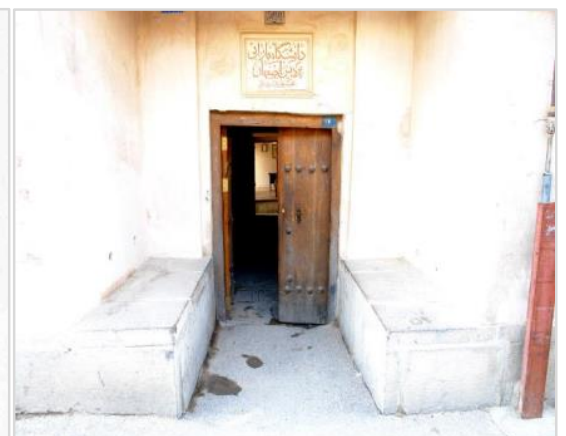

Figure 7: Mysterious places in traditional houses

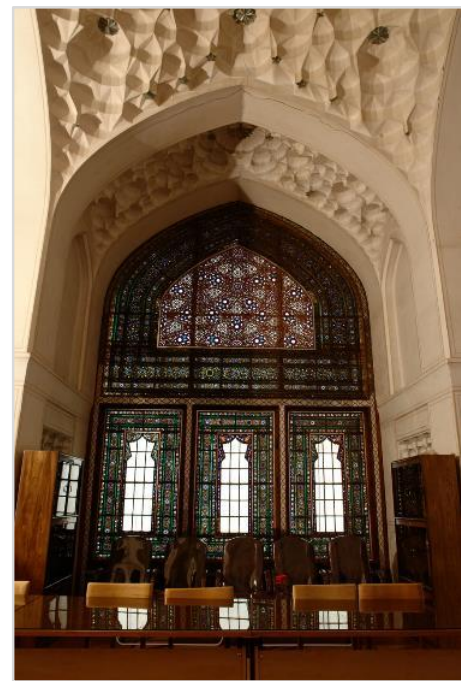

Figure 6: Platforms at door entrance is for social participation 


\section{- Understanding need}

The mystery hidden in these houses is a way to satisfy understanding need (Figure $8 \& 8$ ). Mysterious places in which you should think to understand their order, harmony, details and the wisdom behind them, are designed in these houses in different ways.

\section{- Need of leisure}

There are extensive places to spend leisure times for children and also places like hozkhane at some traditional houses for adults. Having different places with different criteria help people spend their leisure time in different ways

\section{- Identity need}

As mentioned before, hierarchy of places in neighborhood let people shape their identity of place (Figure 9), also places with good criteria with unique character help to increase dependence and identity (Figure 10).

\section{- Need for freedom}

Places with different criteria and also large open spaces let residents to have different option to select the place and therefore reply the need of freedom (Figure 11).

\section{- Competence need}

The rooms in traditional houses are made for different level of competency; the child room, the guest room, the room for married sons, the parents room, which are in a hierarchy level of quality, and this in some extent satisfy competence need. At the other hand, aesthetic elements at home increase creativity of people, also free places which let to think in an open mind space help it, and this bring freedom and competence (Figure12).

\section{- Meaning}

Meaningful places in traditional houses is a base to develop meaning. Myths, stories, similesespecially in ornaments- are too important to bringing meaning to life (Figure13).

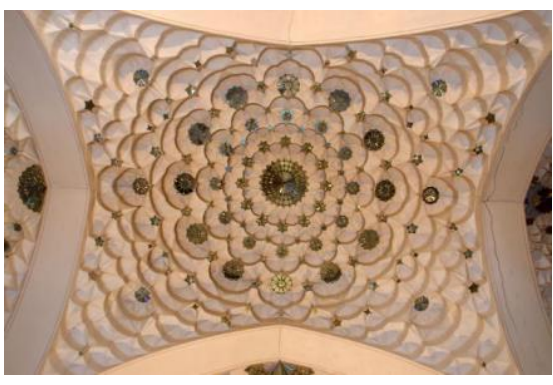

Figure 8: Mysterious ceiling

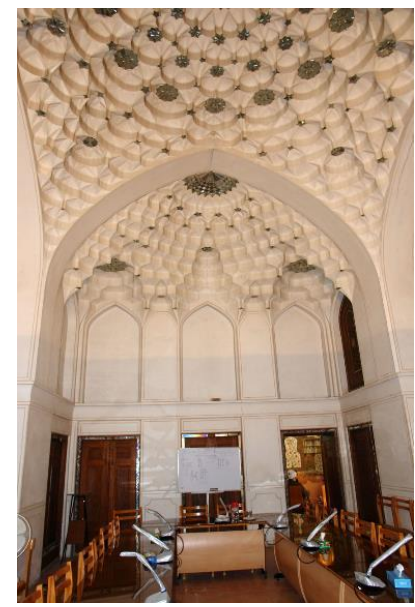

Figure 10.b: Good definition of different places

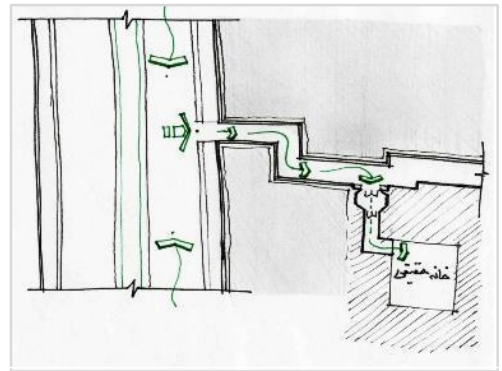

Figure 9: Hierarchy of access to house

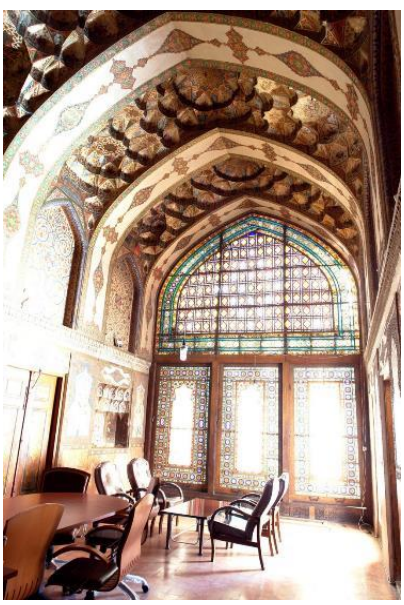

Figure 11: Some places satisfy the freedom need

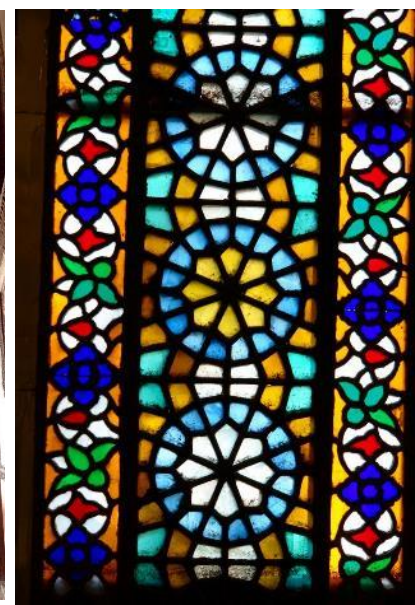

Figure 12: Aesthetic designs at Haghighi house windows

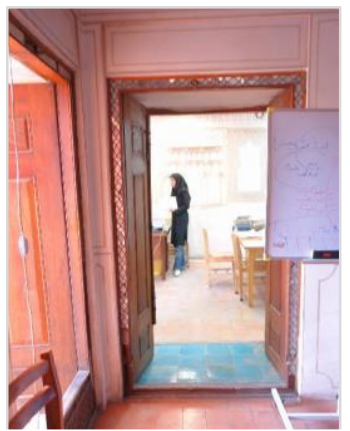

Figure 10.a: Good definition of different places

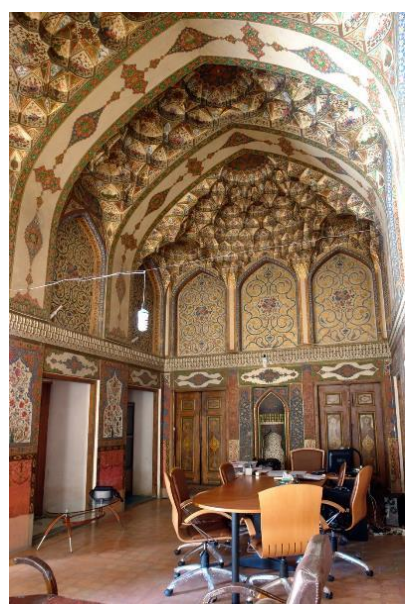

Figure 13: Wall painting full of visualization of 


\section{CONCLUSION}

A house contributes in satisfying human needs as base of everyday life. Traditional houses - in comparison to today ones - were more engaged with these needs. In this survey Haghighi house as a case study has been studied. It seems that traditional houses were built in a more humanistic way, and the human being, as user of these houses were considered. Both physical and psychological aspects of human has specific place in designing a house. These factors were considered as a whole and architects tried to have a balance between them. The logic of responding to needs can be used for contemporary life's places. Therefore the results could be concluded in this way;

Table 3: Strategies for contemporary houses to satisfy more needs

\begin{tabular}{|c|c|c|c|c|c|}
\hline \multicolumn{3}{|c|}{ Need } & Elements & The house elements to & Strategies for \\
\hline \multicolumn{3}{|c|}{ Physiological needs } & $\begin{array}{l}\text { Food, Shelter, rest, } \\
\text { work, sex }\end{array}$ & House as a shelter & $\begin{array}{l}\text { This need is } \\
\text { responded }\end{array}$ \\
\hline \multirow{8}{*}{ 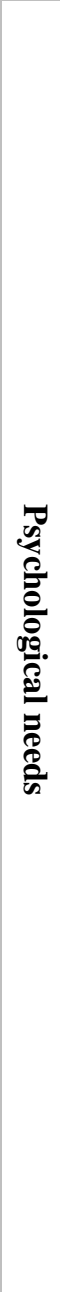 } & \multirow[t]{2}{*}{$\begin{array}{l}\text { Connectio } \\
\text { n }\end{array}$} & Love & Family, friendship & $\begin{array}{l}\text { Good places for a family } \\
\text { home }\end{array}$ & $\begin{array}{l}\text { To consider } \\
\text { psychological } \\
\text { dimensions }\end{array}$ \\
\hline & & Participation & $\begin{array}{l}\text { Duty, rights, } \\
\text { cooperation }\end{array}$ & $\begin{array}{l}\text { Central yards, rooms with } \\
\text { internal interaction, } \\
\text { consecutive views, a } \\
\text { complicated family with } \\
\text { different works }\end{array}$ & $\begin{array}{l}\text { Designing places to } \\
\text { be together }\end{array}$ \\
\hline & \multirow[t]{4}{*}{ Autonomy } & Understanding & $\begin{array}{l}\text { Education, } \\
\text { Thinking }\end{array}$ & $\begin{array}{l}\text { Ornaments, different } \\
\text { criteria of places }\end{array}$ & $\begin{array}{l}\text { Make places with } \\
\text { good criteria, } \\
\text { attention to details }\end{array}$ \\
\hline & & Leisure & $\begin{array}{l}\text { Games, Parties, } \\
\text { relief }\end{array}$ & $\begin{array}{l}\text { Large open spaces, places } \\
\text { with different criteria, } \\
\text { Ornaments, Large } \\
\text { gathering places }\end{array}$ & $\begin{array}{l}\text { Avoiding repetition } \\
\text { of places, attending } \\
\text { to yards, designing } \\
\text { gathering places }\end{array}$ \\
\hline & & Identity & $\begin{array}{l}\text { Being Unique, } \\
\text { Detection }\end{array}$ & $\begin{array}{l}\text { Hierarchy of access, } \\
\text { identity of spaces }\end{array}$ & $\begin{array}{l}\text { Hierarchical access, } \\
\text { Make places with } \\
\text { good criteria }\end{array}$ \\
\hline & & Freedom & $\begin{array}{l}\text { Having options and } \\
\text { selection }\end{array}$ & $\begin{array}{l}\text { Large open spaces, places } \\
\text { with different criteria }\end{array}$ & $\begin{array}{l}\text { Avoiding repetition } \\
\text { of places, attending } \\
\text { to yards }\end{array}$ \\
\hline & \multicolumn{2}{|l|}{ Competence } & Ability, Skill & $\begin{array}{l}\text { Various degrees of using } \\
\text { spaces (depend on age, } \\
\text { marriage, etc) }\end{array}$ & $\begin{array}{l}\text { Designing places } \\
\text { with different levels } \\
\text { (age, education, } \\
\text { abilities) }\end{array}$ \\
\hline & \multicolumn{2}{|l|}{ Meaning } & $\begin{array}{l}\text { Discernment, Life } \\
\text { comprehension }\end{array}$ & $\begin{array}{l}\text { Remembering myths in } \\
\text { ornaments, Metaphors }\end{array}$ & $\begin{array}{l}\text { Bringing metaphors, } \\
\text { and simile in } \\
\text { designs }\end{array}$ \\
\hline
\end{tabular}




\section{REFERENCES}

Abdul Rahim, A. (2013). Architectural heritage study in Iran: Haghighi house. Kuala Lumpor: International Islamic university Malaysia.

Alderfer, C. P. (1969). An empirical test of a new theory of human needs. Organizational behavior and human performance, 4(2), 142-175.

Andersen, S. M., Chen, S., \& Carter, C. (2000). Fundamental human needs: making social cognition relevant. Psychological inquiry, 11(4), 269-318.

Anderson, S. M., Inga , R., \& Serena, C. (1997). The self in relation to others: cognitive and motivational underpinnings. Annals NEw York Academy of Sciences, 818, 233-275.

Coate, R. A., \& Rasati, J. A. (1988). In The Power of Human Needs in World Society. Lynne Rienner Publishers.

Deci, E. L., \& Ryan, R. M. (2000). The "what" and "why" of goal pursuits: Human needs and the self-determination of behavior. Psychology inquiry, 11(4), 227-268.

Frey, L. M., \& Wilhite, K. (2005). Our basic needs: application for understanding the function of behavior. Intervention in school \& clinic, 40(3), 156-160.

Glasser, W. (1999). Choice Theory: A New Psychology of Personal Freedom. New York: Harper Perennial publishers.
Gough, I. (2014). Climate change and sustainable welfare: an argument for the centrality of human needs. London: CASE enquiries.

Griffin, E. A., Andrew, L., \& Glenn, S. (1991). A First Look at Communication Theory. McGraw-Hill.

Heidegger, M. (1971). Poetry, Language, Thoughts. (A. Hofstadter, Trans.) New York: Harper Colphon Books.

Korhonen, H. (2013). Organizational needs: A cocreation and human systems perspective. jbm-Journal of Business Market Management, 214-227.

Maslow, A. H. (1943). A Theory of Human Motivation. Psychological Review(50), 370-396.

Max-neef, M. A. (1991). Human scale development, conception, application and futhur reflections. New York and London: Apex press.

Max-neef, M., Elizalde, A., \& Hopenhayn, M. (1992). Development and human needs. Real-life economics: Understanding wealth creation, 197-213.

Thielke, S., Harniss, M., Hilaire, T., Patel, S., Demiris, G., \& Johnson, K. (2012). Maslow's hierarchy of human needs and the adoption of health-related technologies for older adults. Ageing international, 470-488. 